\title{
The Impact of ECHR and the Case-Law of the ECtHR on the Development of the Right to Legal Assistance in International Criminal Courts (ICTY, ICTR, ICC)
}

\author{
Mykhailo Buromenskyi \\ International Law Department, \\ Taras Shevchenko National University of Kyiv \\ Y. Illienka 36/1, \\ Kyiv 04119, Ukraine \\ E-mail: mykhayloburomenskiy@gmail.com
}

\author{
Vitalii Gutnyk \\ International Law Department, \\ Ivan Franko National University of Lviv \\ Universytetska 1 \\ Lviv 79000, Ukraine \\ E-mail: vitalik_gutnik@ukr.net
}

Abstract: The European Convention on Human Rights and the case-law of the European Court of Human Rights have a significant impact not only on national legal order but also on international criminal courts. The article is dedicated to analyzing that impact in the context of the right to legal assistance.

We ascertain the purpose of the establishment of international criminal courts, the specificity of the right to legal assistance in the European system of human rights protection, the impact of the European Convention on Human Rights on the drafting of statutes of the international criminal courts and influence of the European Convention on Human Rights and case-law of the European Court of Human Rights on the interpretation of the right to legal assistance in the international criminal courts.

Also the primacy of the right to legal assistance is proved, which is provided in the ECHR to the statutes of international criminal courts. At the same time, the international criminal courts, taking into account the purpose of their establishment and jurisdiction, give additional guarantees of the right to legal assistance. 
Keywords: European Convention on Human Rights, European Court of Human Rights, International Criminal Court, right to legal assistance

\section{Introduction}

The twentieth century is distinguished as unprecedented in the scope of massive violations of fundamental human rights committed during international and noninternational armed conflicts. International criminal tribunals were established to prosecute for committing such international crimes when domestic legal order was not able to prosecute persons who commit international crimes. Among these tribunals, the International Criminal Tribunal for the former Yugoslavia (ICTY), the International Criminal Tribunal for Rwanda (ICTR), and the International Criminal Court (ICC) are the most reputed tribunals, established over the past few decades.

There is no doubt that persons who have committed international crimes must be held liable for their crimes; at the same time, they must be provided with the necessary guarantees of a fair trial. In the central place of fair trial guarantees is the right to legal assistance. Amnesty International emphasizes in its Fair Trial Manual that the assistance of a counsel is a primary means of protecting the human rights of accused persons, and in particular their right to fair trial (Amnesty International, 2014). Charika Marasinghe (1995), outlining the value of the right to legal assistance, notes that it is so fundamental that all other rights relating to a fair trial may be worthless if this right is not guaranteed.

Obviously, it is difficult to provide effective defence without the assistance of a counsel. Even if the accused is a professional lawyer, but being in detention, he is not able to physically collect the necessary evidences, and therefore will not provide adequate defence against accusations. Facing with the capabilities and resources available for prosecution side, only the defence counsel's assistance can help the suspect or the accused to defend his position in the case (Marasinghe, 1995). David Fellman emphasizes that the accused needs a lawyer like a patient needs a doctor, and in many cases even more. While the patient can recover himself (without any help), the situation of the accused without the assistance of a defence counsel is unlikely to be improved (Fellman, 1977).

In the international criminal courts, the right to legal assistance is of great importance, especially due to the fact that its cases are extremely complex and could be highly political (Meisenberg, 2007). International criminal courts deal 
with extraordinary crimes, implying much more complicated proceedings, even in comparison with the most complex domestic criminal cases (Whiting, 2009). Therefore, to ensure adequate defence against such prosecution, quite high requirements to legal assistance must be set.

This article focuses on the right to legal assistance, specifically the impact of the European Convention on Human Rights (ECHR) and the case-law of the European Court of Human Rights (ECtHR) on the development of the right to legal assistance in the ICTY, ICTR, and ICC. For this, the following issues are analyzed: the purpose of the establishment of the ICTY, ICTR and ICC; the right to legal assistance in the European system of human rights protection; the impact of the ECHR on the drafting of the ICTY, the ICTR, the ICC; the impact of the ECHR and case-law of the ECtHR on the interpretation of the right to legal assistance in the international criminal courts.

Dialectical, formal logical, comparative, and formal dogmatic methods are used in the analysis.

\section{International criminal courts (ICTY, ICTR, ICC): the purpose of establishment}

The International Criminal Tribunal for the former Yugoslavia (ICTY) was created in accordance to Resolution 827(1993) of the Security Council on 25 May 1993, and the International Criminal Tribunal for Rwanda (ICTR) was established by Resolution 955(1994) of the Security Council on 8 November 1994. Analyzing of these resolutions gives an opportunity to define the aim and reasons of creating the above mentioned Tribunals.

As a justification for the need to establish the ICTY, the Security Council in Resolution 827(1993) expressed its grave alarm at continuing reports of widespread and flagrant violations of international humanitarian law occurring within the territory of the former Yugoslavia, and especially in the Republic of Bosnia and Herzegovina, determining "to put an end to such crimes and to take effective measures to bring to justice the persons who are responsible for them".

In making a decision about the establishment of the ICTY, the Security Council of the United Nations was convinced that

in the particular circumstances of the former Yugoslavia the establishment as an ad hoc measure by the Council of an international 
tribunal and the prosecution of persons responsible for serious violations of international humanitarian law would enable this aim to be achieved and would contribute to the restoration and maintenance of peace (UN Security Council Resolution 827(1993)).

In other words, the purpose of the creation of the ICTY was the need to restore international legal order through the prosecution of persons who committed international crimes on the territory of the former Yugoslavia.

Concerning the ICTR, it is also often called the twin tribunal of the ICTY (Bingham, 2006; Josipovic, 2006). The fact is that the impartial Commission of Experts was established to analyze the situation in Rwanda, in the preliminary report recommended to the Security Council to amend the Statute of the International Criminal Tribunal for the former Yugoslavia to ensure that its jurisdiction covers crimes under international law committed during the armed conflict in Rwanda that began on 6 April 1994 (UN, 1994b).

However, on September 28, 1994, the Letter was sent by the Government of Rwanda to establish the ad hoc international criminal tribunal. As a consequence, the Security Council, by Resolution 955(1994) of 8 November 1994, established the ICTR. Incidentally, the rationale for the creation of the ICTR was quite similar to the ICTY. UN Security Council in the Resolution 955(1994) from 8 November 1994, expressed its grave concern at the reports indicating that genocide and other systematic, widespread and flagrant violations of international humanitarian law had been committed in Rwanda and believed that the establishment of an international tribunal for the prosecution of persons responsible for genocide and the other abovementioned violations of international humanitarian law would contribute to ensuring that such violations were halted and effectively redressed. That is, like the ICTY, de facto the ICTR was established to restore international legal order by bringing to justice those who committed international crimes. The ICTR ceased the existence in December 2015; the ICTY ceased its work in December 2017 (UN, 2019).

The current stage in the development of international criminal justice is associated with the creation and activity of the permanent International Criminal Court (hereinafter referred to as the ICC). Unlike the ICTY and the ICTR, the ICC is a permanent institution and has the power to exercize its jurisdiction over persons for the most serious crimes of international concern. The Court is acting on the basis of a multilateral treaty - the Rome Statute of the International Criminal Court, which was adopted on 17 July 1998 and entered into force on 1 July 2002. The motives for creating the ICC are outlined in the preamble to the Rome 
Statute of the ICC. In particular, already in the first paragraph of the preamble, attention is drawn to that "the States Parties to this Statute are conscious that all peoples are united by common bonds, their cultures pieced together in a shared heritage, and concerned that this delicate mosaic may be shattered at any time". Further in the preamble it is noted that during the 20th century, millions of children, women, and men were victims of unimaginable atrocities that deeply shock the conscience of humanity and that such grave crimes threaten the peace, security, and well-being of the world; the most serious crimes of concern to the international community as a whole must not go unpunished and thus contribute to the prevention of such crimes.

Obviously, such purpose for the establishment of international criminal courts and their jurisdiction require high standards for legal assistance to ensure fair trial.

\section{The right to legal assistance in the European system of human rights protection.}

Regional measures play a fundamental role in promoting and protecting human rights (Vienna Declaration and Programme of Action, 1993). They reflect the values and practices of the states of a particular region (Wilner, 1995-1996), and in general are much more effective than the universal system of human rights protection (Mugwanya, 2000).

The most effective and oldest regional human rights protection system is the European system of human rights protection, at the core of it is the European Convention on Human Rights (ECHR).

An analysis of the drafts of the ECHR makes it possible to maintain that the provisions of the ECHR were based on the norms of the Universal Declaration of Human Rights (1948). The preamble of the ECHR states that governments of European countries take steps for the collective enforcement of certain rights stated in the Universal Declaration that is additional evidence that the Declaration was the basis for the drafting of the ECHR.

The right to legal assistance is provided by Article 6(3)(c) of the ECHR, which guarantees that "everyone charged with a criminal offence has the right to defend himself in person or through legal assistance of his own choosing or, if he has not sufficient means to pay for legal assistance, to be given it free when the interests of justice so require". Consequently, the right to legal assistance 
can be exercized either through (1) the right to legal assistance of own choosing or (2) the right to assigned legal assistance (right to free legal aid), if a suspect or accused person has not sufficient means to pay for legal assistance and when the interests of justice so require.

In analyzing the preparatory work on Article 6 of the ECHR, it becomes apparent that the right to legal assistance of own choosing has not been a subject of any discussions by the drafters. There were no proposals for the exclusion of this right from the text of the ECHR, or to change its wording. This unchanging position of the ECHR's drafters concerning formulation of the right to legal assistance of own choosing confirms not only the importance of this right, but also the constant understanding of its normative content.

Instead, the right to free legal aid was at the heart of the discussions of the ECHR drafters (European Commission of Human Rights, 1956). So, on January 4, 1950, the United Kingdom expressed its views on the formulation of the right of accused to free legal assistance at the ECtHR and suggested that it be worded as follows: "if he has not sufficient means to pay for legal assistance, to be given it free when the interests of justice so require". Subsequently, the problem of the formulation of the right to free legal assistance was considered at the Conference of Senior Officials (on 8-17 June 1950 in Strasbourg). In particular, the French and Italian delegates reminded that such formulation of the right to free legal assistance "made a discrimination between those persons who have the means to pay for a defence counsel and who do not. The latter are therefore given the right, in any case, have legal assistance of their own choosing, while the other are only entitled to the service of defence counsel when the interests of justice so require" (European Commission of Human Rights, 1956)

In the opinion of the French and Italian delegations, this rule will be contrary to the principle of non-discrimination. However, as a result of the discussions, it was recognized that it can be difficult in practice to guarantee for the accused the right to have legal assistance of his own choosing assigned to him free of charge if he did not have the means to pay for it (European Commission of Human Rights, 1956). That is why the wording "if he has not sufficient means to pay for legal assistance, to be given it free when the interests of justice so require" was kept.

Consequently, we can conclude that although the right to free legal aid with the formulation "if he has not sufficient means to pay for legal assistance, to be given it free when the interests of justice so require" has led to discussions, in particular regarding possible discrimination between persons who have the means for the payment for the assistance of the counsel and those who receive 
free legal aid, the ECHR's drafters kept this formulation, justifying this by the fact that if the accused will be given the opportunity to choose a counsel who would provide free legal aid, such right would be difficult to ensure in practice.

Thus, the right to free legal aid, which is included in the text of Article 6 of the ECHR has allowed, on the one hand, to define clearly that the assigned legal aid is provided free of charge, but on the other hand, in the presence of two conditions: (1) the person has not sufficient means to pay for legal assistance; (2) interests of justice require the assigned (free) legal aid (Gillespie \& Weare, 2017). At the same time, such a formulation of the right to free legal aid limited the possibility of choosing the assigned defence counsel (Assy, 2015). It should be stressed that during the ECtHR's activities, it has become clear that effective legal assistance will be possible when a trusting relationship is created between the defence counsel and the client, and that the suspect or accused should be able to choose their defence counsel. Although the possibility of choice of an assigned defence counsel is smaller in scope than the choice of a counsel at his own expense, the ECtHR has repeatedly noted that appointing defence counsel the national courts must have regard to the suspect or accused wishes; those wishes can be overridden only when there are relevant and sufficient grounds for holding that this is necessary in the interests of justice (the cases of Croissant v. Germany [1992]; Lagerblom v. Sweden [2003]; Bezek v. Germany [2015]).

\section{The impact of the ECHR on the drafting of the statutes of ICTY, ICTR, and ICC}

The impact of ECHR on the international criminal tribunals should begin with the establishment of the ICTY. On 22 February 1993, the Security Council included the item entitled 'Establishment of an ICTY' in its agenda and requested the Secretary-General to submit for consideration by Council "a report on all aspects of this matter", taking into account suggestions put forward in this regard by member states (UN Security Council Resolution 808(1993)). The Security Council also included in its agenda: a letter dated 10 February 1993 from the Permanent Representative of France to the United Nations addressed to the Secretary-General (UN, 1993a), and a letter dated 16 February 1993 from the Permanent Representative of Italy to the United Nations addressed to the Secretary-General (UN, 1993b).

The letter dated 10 February 1993 from the Permanent Representative of France included a report of the Committee of French Jurists. The rights of the defence 
was provided in separate subchapter III (F) (paras. 115-120) of this Report. It was emphasized that it would be helpful to include in the Statute a provision guaranteeing the defendant's right to have the assistance of counsel. Moreover, it is stressed that the defendants should benefit fully from all the guarantees provided by the contemporary criminal procedure system.

The Commission of Italian Jurists (in the abovementioned letter from 16 February 1993) prepared not only a report, but also a Draft Statute of the ICTY with a commentary on each article. Article 11 of the Draft was entitled 'Principles of proceedings' and included, among others, the right to legal assistance (Art. 11(1) of the Draft). The procedural principles contained in Article 11 of the Draft, on the opinion of the Commission are designed to safeguard the defendant; these principles are set forth under Article 6(3) of the ECHR.

Carrying out the task of the UN Security Council in accordance with Resolution 808(1993), the Secretary-General of the United Nations made a report in which he determined that it is axiomatic that the International Tribunal must fully respect internationally recognized standards regarding the rights of the accused in all stages of its proceedings (UN, 1993c). Consequently, during the drafting of the Statute of the ICTY, the international standards of rights to legal assistance were taken into account, in particular those contained in the ECHR. Moreover, comparing of Article 21(4)(d) of the Statute of the ICTY and Article 6(3)(c) of the ECHR allows highlighting the very similar formulation of the right to defence in the both documents, which is an additional argument of the influence of the relevant norms of the ECHR (in the context of the right to legal assistance) on the drafting of the Statute of the ICTY.

Regarding the ICTR, as already mentioned above, it has often been called also the twin tribunal of the ICTY (Bingham, 2006; Josipovic, 2006; MacDonald \& Swaak-Goldman, 2000); the Statute of the ICTR contains completely identical procedural rules with the ICTY, including those relating to the right to legal assistance. The ICTR's practice concerning the legal assistance is identical to that of the ICTY. Moreover, the ICTR has tried to make decisions using the practice of the ICTY on similar issues of the right to defence (Prosecutor $v$. Ferdinand Nahimana, Hassan Ngeze and Jean Bosco Barayagwiza [2003]; Prosecutor v. Ferdinand Nahimana, Jean Bosco Barayagwiza and Hassan Ngeze [2007]).

The question of establishing the permanent international criminal court has a much longer history. So, after a 40-year break, the question of the creation of the ICC moved from a dead point only in the early 1990s (Sands, 2003). The UN General 
Assembly, in its resolution of 25 November 1992, powered the International Law Commission to draft a Statute of the International Criminal Court.

In the Draft of the ICC Statute, drafted by the International Law Commission of 1994, the right to defence was regulated in Article 41 (rights of the accused). In commenting on this article, the International Law Commission drew attention to the fact that it contains the minimum guarantees that the accused is entitled to in court proceedings (UN, 1994a). This article reflected the basic rights of the accused, including right to legal assistance, which are set forth in Article 14 of the ICCPR and Article 6 of the ECHR.

Further, the General Assembly of the United Nations established the Ad hoc Committee on the establishment of an International Criminal Court, whose report was considered at the Fiftieth Session of the General Assembly (1995). In this Report, the Ad hoc Committee paid particular attention to the right to free legal aid. The Ad hoc Committee stressed,

the issue of mandatory legal assistance was viewed as particularly important in view of the seriousness of the crimes within the jurisdiction of the court. Emphasis was placed in this context on the need to establish rules on the qualifications, powers and remuneration of defence attorneys and on the procedure governing the appointment of court-assigned attorneys (UN, 1995).

The next step of the UN General Assembly was the establishment of the Preparatory Committee, which submitted the report to the General Assembly with a sufficient detailing of the right to legal assistance. In particular, the Preparatory Committee noted that the Statute should provide the right to an assigned defence counsel if the accused could not afford one. Moreover, in the opinion of the Committee, a list of defence counsel should be presented to allow the accused a choice of defence counsel. It was suggested that qualification for defence counsel should be based on the capacity to practice before the highest criminal court in the country; in the case of court-appointed counsel, a panel could be established to review counsel according to such criteria as high moral character, competency and relevant experience (UN, 1996).

In contrast to the ECHR and the case-law of the ECtHR, the drafters of the ICC Statute considered the need to include in the Statute the requirements for qualifications of defence counsels, the right to choose the assigned defence counsel among those included in the list of defence counsels.

It is worth emphasizing that the ICC Statute provides the right to defence 
in several articles. The ICC Statute, compared with the Statutes of previous international criminal courts, provided the right to legal assistance for the suspects (in the ICTY and the ICTR this right for suspects was provided only in the Rules of Procedure and Evidence).

In particular, Article 55(2)(c) of the ICC Statute provides the right "to have legal assistance of the person's choosing, or, if the person does not have legal assistance, to have legal assistance assigned to him or her, in any case where the interests of justice so require, and without payment by the person in any such case if the person does not have sufficient means to pay for it".

The right of the accused to legal assistance, provided by Article 67(1)(d) of the ICC Statute, is very similar to the formulation of Article 55(2)(c) (for suspects): "to conduct the defence [...] through legal assistance of the accused's choosing, to be informed, if the accused does not have legal assistance, of this right and to have legal assistance assigned by the Court in any case where the interests of justice so require, and without payment if the accused lacks sufficient means to pay for it". This reaffirms a common understanding of the scope of the right to legal assistance for all persons who could potentially be found guilty (or acquitted) of committing an international crime, regardless of the stage of the proceedings.

At the same time, while taking into account the perceived standards of the ECtHR concerning the right to legal assistance, international criminal courts have moved on. As K. Kremens emphasizes, "neither human rights law nor the historical tribunals have resolved the question of the level of education and experience a lawyer ought to possess in order to practice before courts and tribunals. International criminal trials are the ones that should be regarded with particular attention" (Kremens, 2011) and that confirms the progressive development in guaranteeing the right to legal assistance by modern international criminal courts.

\section{The impact of the ECHR and the case-law of the ECtHR on the interpretation of the right to legal assistance in international criminal courts}

International criminal courts are not parties to, and therefore not formally bound by the ECHR nor the case-law developed by the ECtHR (Cryer et al., 2010). However, as already noted, the rights of the accused contained in international human rights instruments, including the ECHR, were the basis of relevant rights 
of the accused during establishing the ICTY, the ICTR, and the ICC. As a result, we can talk about the primacy of the right to legal assistance, which is reflected in the ECHR and the case-law of the ECtHR to the statutes of international criminal courts.

This is also evidenced by the practice of the ICTY, the ICTR and the ICC. Trial chambers of the ICTY in the cases of Prosecutor v. S. Milosevic [2004], Prosecutor v. V. Seselj [2003], Prosecutor v. Z. Tolimir, R. Miletic, M. Gvero [2005], Prosecutor v. J. Prlic, B. Stojic, S. Praljak, M. Petkovic, V. Coric, B. Pusic [2006] and others, considering the question of the possibility of appointing a defence counsel for the accused, examined the normative content of the right to legal assistance in the ECHR and the practice of the ECtHR.

Similarly, in the cases related to the rights to legal assistance of the ICTR (Prosecutor v. Phénéas Munyarugarama [2012]) and the ICC (The Prosecutor v. Germain Katanga and Mathieu Ngudjolo Chui [2012]; The Prosecutor v. Thomas Lubanga Dyilo [2016]) referred to the abovementioned Convention as well as the case-law of the ECtHR.

The international criminal courts have adopted the interpretation of the right to legal assistance from the ECtHR, perceiving it as the core of ensuring a fair trial. In cases of international criminal courts raising the issue of the right to legal assistance, the abovementioned courts substantiated their decisions by referring to similar provisions of the ECHR in the interpretation of the ECHR. This is evidence of the establishment by the ECHR of the minimum standards for compliance with the right to legal assistance of arms and its application by international criminal courts.

Moreover, the international criminal courts use the provisions of the ECHR as international legal custom (Grover, 2014). For example, in the case of Barayagwiza, the ICTR clarifies that

regional human rights treaties, such as the European Convention on Human Rights and the American Convention on Human Rights, and the jurisprudence developed thereunder, are persuasive authority which may be of assistance in applying and interpreting the Tribunal's applicable law. Thus, they are not binding of their own accord on the Tribunal. They are, however, authoritative as evidence of international custom. (Prosecutor v. J. Barayagwiza [1999])

This, again, confirms the impact of the ECHR and the case-law of the ECtHR on the statutes and the practice of the international criminal courts. 
Hence, international criminal courts observe the standards of the ECtHR concerning the right to legal assistance. However, taking into account the purpose of their creation and jurisdiction, they establish additional guarantees to the right to legal assistance. For example, the case-law of the ECtHR does not establish requirements for the qualification of a defence counsel; this issue is within the competence of the state. Instead, international criminal courts not only establish the requirements for the qualification of defence counsel, but these requirements are much higher than in accusation procedures in national criminal proceedings. In particular, under Rule 45(B) of the Rules of Procedure and Evidence of the ICTY and Article 14(A) of the Directive on the Assignment of Defence Counsel of the ICTY, defence counsel should possess at least seven years of relevant experience whether as a judge, prosecutor, attorney or in some other capacity, in criminal proceedings and he must possess established competence in criminal law and/or international criminal law, international humanitarian law, and international human rights law. Rule 45(A) of the Rules of Procedure and Evidence of the ICTR and Article 13(i) of the Directive on the Assignment of Defence Counsel of the ICTR prescribe also "relevant" experience of at least seven years, but do not provide the list of the positions where the defence counsel should have such experience (Gutnyk, 2015). The lack of concretization of "relevant" experience was interpreted by scientists as arbitrary requirement (Leaney, 2008). In accordance with Rule 22(1) of the Rules of Procedure and Evidence of the ICC and Regulation 67(1) of the ICC, the minimum duration of experience is ten years for lead counsel and eight for associate counsel. Also, the ICC specifies the spheres and positions of those who should have this experience: judge, prosecutor, advocate or in other similar capacity in criminal proceedings.

In addition to that, the statutes of international criminal courts, in contrast to the ECHR, do not contain norms that would oblige states to provide the appropriate level of guarantees of the right to legal assistance in domestic legal systems. At the same time, the statutes of international criminal courts enrich the judicial practice of national courts and stimulate the prosecution, demonstrating considerable attention to the prevention of serious human rights violations (Schabas, 2011). Therefore, despite the absence of an obligation for states to adhere to the appropriate level of standards of international criminal courts, based on the history of such standards of the right to defence, their legal nature, based on the provisions of the ECHR and the practice of the ECtHR, it can be argued that the statutes of international criminal courts implicitly affect the relevant domestic criminal procedural legislation. 


\section{Conclusion}

The concept of the right to legal assistance in criminal proceedings of the ECHR (especially in the context of its interpreting by the ECtHR) has been taken as a basis for the drafting of the relevant provisions of the statutes of modern international criminal courts.

The right to legal assistance is provided in Article 21(4)(d) of the Statute of the ICTY, Article 20(4)(d) of the Statute of the ICTR and Article 67(1)(d) of the Statute of the ICC. Indeed, the right to defence in criminal proceedings in international criminal courts is provided in the same wording as in the ECHR. The reason for this is that the right to legal assistance containing in the ECHR became the basis for the drafting of the relevant right in the Statute of the ICTY and further in the Statute of the ICTR and the Statute of the ICC. As a consequence, it proves the primacy of the right to legal assistance, provided in the ECHR, in the statutes of international criminal courts. But international criminal courts, taking into account the purpose of their establishment and jurisdiction, give additional guarantees of the right to legal assistance. For example, the case-law of the ECtHR does not establish the requirements for the qualification of a defence counsel; this issue is within the competence of the state. Instead, international criminal courts not only establish the requirements for the qualification of defence counsel, but these requirements are much higher than in domestic legal orders.

In addition, in interpreting the right to legal assistance, international criminal courts apply the relevant practice of the ECtHR. This makes it possible to talk about the substantive impact of the ECHR and the case-law of the ECtHR on international criminal law in the context of the right to legal assistance.

Mykhailo Buromenskyi is doctor of legal sciences, professor of International Law Department, Taras Shevchenko National University of Kyiv, head of the Ukrainian delegation for participation in the work of the Council of Europe's Group of States against Corruption (GRECO), former ad hoc judge at the European Court of Human Rights. His research interests are the case-law of the European Court of Human Rights, anticorruption policy.

Vitalii Gutnyk, is doctor of legal sciences, associate professor at the International Law Department, Ivan Franko National University of Lviv. His research interests are the caselaw of international criminal courts, right to defence in international criminal courts. 
The Impact of ECHR and the Case-Law of the ECtHR on the Development of the Right to Legal Assistance in International Criminal Courts (ICTY, ICTR, ICC)

\section{References}

Amnesty International (2014), Fair Trial Manual, 2nd ed., London: Amnesty International.

Assy, R. (2015), Injustice in Person: The Right to Self-representation, Oxford: Oxford University Press. https://doi.org/10.1093/acprof:oso/9780199687442.001.0001

Bezek v. Germany [2015], ECtHR, 4211/12 and 5850/12, 21.04.2015. Retrieved from http://hudoc.echr.coe.int/eng?i=001-154555 [accessed 24 Aug 2019]

Bingham, L. (2006), 'Strategy or process? Closing the international criminal tribunals for the former Yugoslavia and Rwanda,' Berkeley Journal of International Law, vol. 24, no. 2, pp. 687-717.

Croissant v. Germany [1992], ECtHR, no. 13611/88, 25.9.1992. Retrieved from http:// hudoc.echr.coe.int/eng?i=001-57736 [accessed 24 Aug 2019]

Cryer, R.; Friman, H.; Robinson, D. \& Wilmshurst, E. (2010), An Introduction to International Criminal Law and Procedure, 2nd ed., Cambridge: Cambridge University Press. https://doi.org/10.1017/CBO9780511760808

European Commission of Human Rights (1956), Document DH(56)11 CDH(68)3 prepared by Preparatory Work on Article 6 of the European Convention on Human Rights (1956). Information Document prepared by the Secretariat of the European Commission of Human Rights. Doc. DH(56)11 CDH(68)3, 8.10.1956. Retrieved from http:/www.echr.coe.int/LibraryDocs/Travaux/ECHRTravaux-ART6-DH(56) 11-EN1338886.PDf [accessed 24 Aug 2019]

European Convention on Human Rights (1950), 4.11.1950. Retrieved from https://www. echr.coe.int/Documents/Convention_ENG.pdf [accessed 24 Aug 2019]

Fellman, D. (1977), The Defendant's Rights Today, London \& Madison, WI: University of Wisconsin Press.

General Assembly Resolution A/47/10(1993), adopted by the General Assembly (on the report of Sixth Committee (A/47/586), 9 February 1993. Retrieved from https:// undocs.org/en/A/RES/47/34 [accessed 24 Aug 2019]

Gillespie, A. \& Weare S. (2017), The English Legal System, Oxford: Oxford University Press. https://doi.org/10.1093/he/9780198785439.001.0001

Grover, L. (2014), Interpreting Crimes in the Rome Statute of the International Criminal Court, Cambridge: Cambridge University Press.

https://doi.org/10.1017/CBO9781107705586

Gutnyk, V. (2015), 'The requirements for qualification of defence counsel in the international criminal courts and tribunals,' Teisé, vol. 95, pp. 182-192. https://doi.org/10.15388/Teise.2015.95.7481

Josipovic, I. (2006), 'Responsibility for war crimes before national courts in Croatia,' International Review of the Red Cross, vol. 88, no. 861, pp. 145-168.

https://doi.org/10.1017/S1816383106000099

Tallinn University of Technology (ISSN 2228-0588), Vol. 9, No. 3 (28) 
Kremens, K. (2011), 'The protection of the accused in international criminal law according to the human rights law standard,' Wroclaw Review of Law, Administration \& Economics, vol. 1, pp. 26-48. https://doi.org/10.2478/wrlae-2013-0026

Lagerblom v. Sweden [2003], ECtHR, 26891/95, 14.1.2003. Retrieved from http:// hudoc.echr.coe.int/eng? $\mathrm{i}=001-60884$ [accessed 24 Aug 2019]

Leaney, E. (2008), 'Assignment of counsel of choice to indigent accused at the ICTR: an analysis of a threat to fair trial rights and what may be done about it,' New Zealand Yearbook of International Law, vol. 6, pp. 239-272.

MacDonald, G. K. \& Swaak-Goldman, O. Q. (2000), Substantive and Procedural Aspects of International Criminal Law. Volume 1: Commentary, Hague: BRILL.

Marasinghe, C. (1995), 'The right to legal assistance in international law, with special reference to the ICCPR, the ECHR, and the ACHR,' Asian Yearbook of International Law, vol. 5, pp. 15-44.

Meisenberg, S. M. (2007), 'The right to legal assistance at the International Criminal Tribunal for Rwanda: a review of its jurisprudence,' in E. Decaux, A. Dieng \& M. Sow (eds.) From Human Rights to International Criminal Law: Studies in Honour of an African Jurist, the Late Judge Laïty Kama, Martinus Nijhoff Publishers, pp. 125-157. https://doi.org/10.1163/ej.9789004160552.i-776.30

Mugwanya, G. (2000), 'Realizing universal human rights norms through regional human rights mechanisms: reinvigorating the African system,' Indiana International \& Comparative Law Review, vol. 10, pp. 35-50. https://doi.org/10.18060/17527

Prosecutor v. J. B. Barayagwiza [1999], ICTR, no. ICTR-97-19 (Appeals Chamber Decision), 3.11.1999. Retrieved from http://www.unictr.org/Portals/0/Case/ English/Barayagwiza/decisions/dcs991103.pdf [accessed 27 Aug 2019]

Prosecutor v. Ferdinand Nahimana, Hassan Ngeze and Jean Bosco Barayagwiza [2003],

Decision on the motion to stay the proceedings in the trial of Ferdinand Nahimana, ICTR, no. ICTR-99-52-T, 5.6.2003. Retrieved from https://jrad.irmct.org/view. $\mathrm{htm} ? \mathrm{r}=216405 \& \mathrm{~s}=$ [accessed 25 Aug 2019]

Prosecutor v. Ferdinand Nahimana, Jean Bosco Barayagwiza and Hassan Ngeze [2007], Judgement, ICTR, no. ICTR-99-52-Am, 28.11.2007. Retrieved from https:/unictr.irmct.org/sites/unictr.org/files/case-documents/ictr-99-52/appealschamber-judgements/en/071128.pdf [accessed 25 Aug 2019]

Prosecutor v. J. Prlic, B. Stojic, S. Praljak, M. Petkovic, V. Coric, B. Pusic [2006], Decision On Assignment Of Defence Counsel, para. 10, ICTY, no. IT-04-74-PT, 15.12.2006. Retrieved from http://www.icty.org/x/cases/prlic/tdec/en/060215.htm [accessed 27 Aug 2019]

Prosecutor v. S. Milosevic [2004], Decision on Interlocutory Appeal of the Trial Chamber's Decision on the Assignment of Defense Counsel, ICTY, no. IT-0254-AR73.7, 1.11.2004. Retrieved from http://www.icty.org/x/cases/slobodan milosevic/acdec/en/041101.htm [accessed 27 Aug 2019] 
Prosecutor v. Phénéas Munyarugarama [2012], Decision on the prosecutor's request for referral of the cases to the Republic of Rwanda, ICTR, no. ICTR-02-79R11bis, 28.6.2012. Retrieved from http://w.unictr.org/sites/unictr.org/files/casedocuments/ictr-02-79-r11bis/trial-decisions/en/120628.pdf [accessed 27 Aug 2019]

Prosecutor v. V. Seselj [2003], Decision on Prosecution's Motion for Order Appointing Counsel to Assist Vojislav Seselj with his Defence, ICTY, no. IT-03-67-PT, 9.5.2003. Retrieved from http://www.icty.org/x/cases/seselj/tdec/en/030509.htm [accessed 27 Aug 2019]

Prosecutor v. Z. Tolimir, R. Miletic, M. Gvero [2005], Decision on Appointment of Co-counsel for Radivoje Miletic, ICTY, no. IT-05-88-PT, 28.12.2005. Retrieved from http://www.icty.org/x/cases/popovic/tdec/en/050928.htm [accessed 27 Aug 2019]

Sands, P. (2003), From Nuremberg to The Hague: The Future of International Criminal Justice, Cambridge: Cambridge University Press. https://doi.org/10.1017/ CBO9780511494086

Schabas, W. (2011), An Introduction to the International Criminal Court, Cambridge: Cambridge University Press.

The Prosecutor v. Germain Katanga and Mathieu Ngudjolo Chui [2012], Situation in the Democratic Republic of the Congo, no. ICC-01/04-01/07, Decision on the implementation of Regulation 55 of the Regulations of the Court and severing the charges against the accused persons, 21 November. Retrieved from https://www. icc-cpi.int/CourtRecords/CR2012_10236.PDF [accessed 27 Aug 2019]

The Prosecutor v. Thomas Lubanga Dyilo [2016], Situation in the Democratic Republic of the Congo, no. ICC-01/04-01/06, Decision on the Request of the Defence for Thomas Lubanga Dyilo seeking his Appearance via Video-Link at the Hearings of 11, 13 and 14 October 2016, 6.10.2016. Retrieved from https://www.icc-cpi.int/ CourtRecords/CR2017_04423.PDF [accessed 27 Aug 2019]

UN (1993a), Letter dated 10 February 1993 from the Permanent Representative of France to the United Nations addressed to the Secretary-General, S/25266. Retrieved from http://repository.un.org/bitstream/handle/11176/50551/S_25266EN.pdf [accessed 24 Aug 2019]

UN (1993b), Letter dated 16 February 1993 from the Permanent Representative of Italy to the United Nations addressed to the Secretary-General, S/25300. Retrieved from https://www.un.org/ga/search/view_doc.asp?symbol=S/25300 [accessed 24 Aug 2019]

UN (1993c), Report of the Secretary-General Pursuant to Paragraph 2 of Security Council Resolution 808 (1993), presented 3 May 1993 (S/25704). Retrieved from https://undocs.org/S/25704 [accessed 24 Aug 2019] 
UN (1994a), Draft commentary to Parts 4 and 5 of the Draft Statute, Report of the Working Group on a draft Statute for an International Criminal Court, UN Doc. A/CN.4/L.491/Rev.2/Add.2, 18 July 1994. Retrieved from http://legal.un.org/ docs/?symbol=A/CN.4/L.491/Rev.2/Add.2 [accessed 24 Aug 2019]

UN (1994b), Preliminary report of the Independent Commission of Experts. Annex to Letter dated 1 October 1994 from the Secretary-General to the President of the Security Council, UN Doc. S/1994/11254 October. Retrieved from https://undocs. org/S/1994/1125 [accessed 23 Aug 2019]

UN (1995), Report of the Ad Hoc Committee on the Establishment of an International Criminal Court, UN Doc. A/50/22. Retrieved from https://www.legal-tools.org/ doc/b50da8/pdf/ [accessed 25 Aug 2019]

UN (1996), Report of the Preparatory Committee on the Establishment of an International Criminal Court (1996), UN Doc. A/51/22. Retrieved from https://www.legal-tools. org/doc/e75432/pdf/ [accessed 25 Aug 2019]

UN (2019), International Tribunals. Retrieved from https:/www.un.org/securitycouncil/ content/repertoire/international-tribunals [accessed 24 Aug 2019]

UN Security Council Resolution 808(1993), adopted by the Security Council on 22 February 1993. Retrieved from https://undocs.org/S/RES/808(1993) [accessed 24 Aug 2019]

UN Security Council Resolution 827(1993), adopted unanimously on 25 May 1993. UN Doc. S/RES/827(1993). Retrieved from http://www.un.org/en/ga/search/ view_doc.asp?symbol=S/RES/827(1993) [accessed 23 Aug 2019]

UN Security Council Resolution 955(1994), adopted on 8 November 1994. UN Doc. S/RES/955(1994). Retrieved from http://www.un.org/en/ga/search/view_doc. asp?symbol=S/RES/955(1994) [accessed 23 Aug 2019]

Vienna Declaration and Programme of Action (1993), UN. Doc. A/CONF.157/23. Retrieved from https://www.ohchr.org/EN/ProfessionalInterest/Pages/Vienna. aspx [accessed 24 Aug 2019]

Whiting, A. (2009), 'In international criminal prosecutions, justice delayed can be justice delivered,' Harvard International Law Journal, vol. 50, pp. 323-364.

Wilner, G. (1995-1996), 'Reflection of regional human rights law,' Georgia Journal of International and Comparative Law, vol. 25, pp. 407-426. 